\title{
ELASTASE ACTIVITY OF COCCIDIOIDES IMMITIS
}

\author{
P. NzIRAMASANGa AND D. M. LUPAN* \\ Department of Microbiology, School of Medicine, \\ University of Nevada, Reno, Nevada 89557 U.S.A.
}

\begin{abstract}
Summary. Twenty-two strains of Coccidioides immitis were tested for the ability to hydrolyse elastin. Screening assays with Czapek's or Tryptic Soy Agar supplemented with 0.5\% elastin demonstrated that 21 strains $(95 \%)$ were elastolytic. In broth cultures, elastase activity was induced by incorporation of insoluble elastin into the medium and induction was suppressed by supplementation with yeast extract. $C$. immitis appears to be unique amongst dimorphic fungal pathogens in its digestion of elastin.
\end{abstract}

\section{INTRODUCTION}

The elastolytic activity of fungi has been investigated by Rippon and Varadi (1968) in 70 species and by Hopsu-Havu, Sonck and Tunnela (1972) in 185 isolates. These studies found that many fungi hydrolyse elastin but, with the exception of a single strain of Coccidioides immitis, the dimorphic pathogens showed no elastolysis.

Because only a single strain of $C$. immitis was studied, the present investigation was undertaken to determine the frequency of elastolysis by strains of $C$. immitis.

\section{MATERIALS AND METHODS}

Fungus strains. The strains of $C$. immitis used were supplied by Dr M. Huppert, Veterans Administration Hospital, San Antonio, TX 78284, USA and maintained on glucose-yeast extract agar $(2 \%: 1 \%: 2 \%)$.

Screening assays. A survey of elastase activity was undertaken with Czapek's agar containing bovine elastin (Sigma Chemical Co., St Louis, MO, 63178, USA) $0 \cdot 5 \%$. Tryptic Soy Agar (Difco Labs, Detroit, MI 48216, USA) with elastin $0.5 \%$ was also used to determine whether or not organic nutrients affected growth and enzyme production. Bi-petri plates were seeded with the C. immitis strains, incubated at $30^{\circ} \mathrm{C}$, and examined daily for elastolysis. Digestion was observed as a clearing of particulate elastin in the agar and zones of digestion were measured through the reverse of the plates.

Growth and elastase production. Six strains of C. immitis (C-39, C-40, C-46, C-60, C-108 and $\mathrm{C}-187)$ were selected to study the relationship between fungal growth and elastase production. Spore and mycelium suspensions in saline were shaken to fragment the mycelium and suspend the arthrospores. Viability was determined by pour plates in glucose-yeast extract agar.

Strains of C. immitis were inoculated into $50 \mathrm{ml}$ of Czapek's fluid, Czapek's fluid with bovine elastin $0.5 \%$ and Czapek's fluid with elastin and yeast extract $0.1 \%$. Each flask received $2.5 \times 10^{4}$ $\mathrm{cfu}$ and 15 flasks were employed for each medium. These were incubated at $35^{\circ} \mathrm{C}$ on a gyrotory

Received 19 Mar. 1984; revised version accepted 4 Jul. 1984.

*Please address any correspondence to Dr D. M. Lupan. 
(150 rpm) shaker. Three flasks of each medium were harvested at 3-day intervals during a 15-day period. Mycelium and spores were removed by centrifugation (1000 $g$ for $15 \mathrm{~min}$ ) and the supernate sterilised by filtration. The fluid was assayed for elastase activity as detailed below. The culture fluid was stored at $-20^{\circ} \mathrm{C}$ until the total protein could be estimated. The mycelial mats were heated $\left(10 \mathrm{~min}\right.$ at $\left.121^{\circ} \mathrm{C}\right)$, washed twice with $100-\mathrm{ml}$ volumes of distilled $\mathrm{H}_{2} \mathrm{O}$, and freeze-dried for total carbohydrate estimation.

Elastase assay. This was modified from that of Sachar et al. (1955) for mammalian elastase. Duplicate lots of $10 \mathrm{mg}$ of orcein-elastin (Sigma) were placed in acid-cleaned $13 \times 100 \mathrm{~mm}$ screw-capped tubes with $1.5 \mathrm{ml}$ of $0.2 \mathrm{M}$ tris-maleate buffer, $p \mathrm{H} 8.5$. A sample $(0.5 \mathrm{ml})$ of the unknown enzyme solution was added, and the tubes were placed on a rotator at $37^{\circ} \mathrm{C}$ for $2 \mathrm{~h}$. To stop the reaction, $2.0 \mathrm{ml}$ of $0.5 \mathrm{M}$ phosphate buffer, $p \mathrm{H} 6.0$, was added. The tubes were centrifuged at $1000 \mathrm{~g}$ for $10 \mathrm{~min}$ to sediment undigested elastin and the absorbance of the supernate at $590 \mathrm{~nm}$ was determined. The units of absorbance were compared with standard curve values obtained by digestion of orcein elastin with porcine elastase (Sigma). Heat treated $\left(10 \mathrm{~min}\right.$ at $\left.100^{\circ} \mathrm{C}\right)$ control samples were also included in each elastase assay.

Carbohydrate assay. Carbohydrate was taken as a measure of fungal growth and determined by the method of Dubois et al. (1956) with dextrose as the standard.

Protein assay. Total protein was determined by the method of Lowry et al. (1951). In instances where elastin-digestion products would interfere with the assay, macromolecular protein was precipitated by adding aqueous saturated ammonium sulphate to the culture fluid to achieve a final concentration of $75 \%$ saturation. The precipitate was collected by centrifugation $(1500 \mathrm{~g}$ for $10 \mathrm{~min}$ ), and the supernate discarded. The pellet was dissolved in $1 \mathrm{ml}$ of deionised water, dialysed overnight against deionised water, and assayed for total protein.

\section{RESULTS}

\section{Elastase survey}

Twenty-one $(95 \%)$ of the strains tested hydrolysed elastin (table I). In some instances, the zone of elastin digestion was clearly larger than the colony diameter, but more often it was not (fig. 1; table I). Strain C-605 failed to grow on the Czapek's-elastin agar medium (CPK-E). This strain grew on the elastin-supplemented TSA (TSA-E), but failed to digest elastin.

An average digestion zone diameter of $2.7 \mathrm{~cm}$ was obtained on the CPK-E medium while identical strains grown on the enriched agar medium (TSA-E) had a significantly $(\mathrm{p}<0.05)$ smaller average diameter $(2.26 \mathrm{~cm})$.

The colonies of $C$. immitis had a better growth rate on TSA-E (table I); however, elastase activity, as measured by zones of digestion, was decreased. Furthermore, strains (C-62, C-80, C-238, C-606, and C-607) that were positive on the minimal medium (CPK-E) gave either questionable or negative results (table I) on the enriched medium (TSA-E).

When the CPK-E and TSA-E bi-petri plates were held for an additional 2 weeks at $4^{\circ} \mathrm{C}$, an apparent increase in elastase activity was noted (fig. 2; table II). The average digestion zone on both media was significantly larger than the zone observed after the initial incubation. Moreover, the doubtful strains (C-62, C-80, and C-607) were easily discerned as positive which suggested that supplemental incubation at $4^{\circ} \mathrm{C}$ was necessary for verifying the elastase activity of questionable or presumably negative strains.

\section{Elastase production in liquid culture}

Cultivation on CPK-E and TSA-E suggested that the presence of extra nutrients 


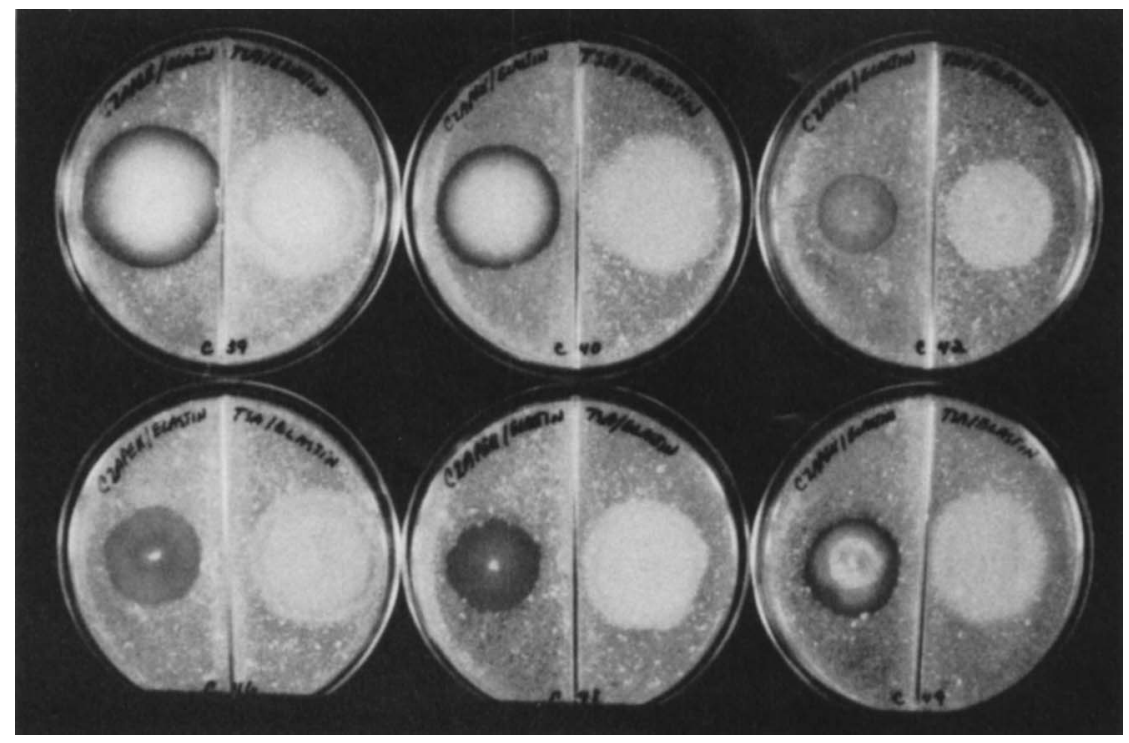

FIG. 1.-Elastase activity of six strains (C39, C40, C42, C46, C48, C49) of C. immitis cultured on Czapek's elastin agar (left half of plate) and Tryptic Soy elastin agar (right half of plate) after incubation at $30^{\circ} \mathrm{C}$ for 1 week. Each culture medium was supplemented with elastin $0.5 \%$ which is particulate and insoluble. Elastase activity is indicated by clearing of insoluble elastin in the agar under each fungal colony.

TABLE I

Elastase activity of C. immitis after incubation for 1 week at $30^{\circ} \mathrm{C}$ on Czapek's and Tryptic Soy Agar media supplemented with elastin $0.5 \%$.

\begin{tabular}{|c|c|c|c|c|}
\hline \multirow[b]{3}{*}{ Strain no. } & \multicolumn{4}{|c|}{ Growth and activity of strain on } \\
\hline & \multicolumn{2}{|c|}{ Czapek's Agar } & \multicolumn{2}{|c|}{ Tryptic Soy Agar } \\
\hline & $\begin{array}{l}\text { Colony } \\
\text { diameter } \\
\text { (cm) }\end{array}$ & $\begin{array}{l}\text { Elastin } \\
\text { hydrolysis } \\
\text { diameter } \\
\text { (cm) }\end{array}$ & $\begin{array}{l}\text { Colony } \\
\text { diameter } \\
(\mathrm{cm})\end{array}$ & $\begin{array}{l}\text { Elastin } \\
\text { hydrolysis } \\
\text { diameter } \\
\text { (cm) }\end{array}$ \\
\hline-39 & 3.7 & $3 \cdot 7$ & $3 \cdot 8$ & $2 \cdot 5$ \\
\hline C -40 & $3 \cdot 2$ & $3 \cdot 2$ & 3.7 & 1.5 \\
\hline C -42 & $2 \cdot 5$ & $2 \cdot 0$ & $2 \cdot 8$ & 1.7 \\
\hline C-46 & $2 \cdot 6$ & $2 \cdot 4$ & $3 \cdot 5$ & $3 \cdot 0$ \\
\hline C-48 & $2 \cdot 5$ & $2 \cdot 3$ & $3 \cdot 4$ & $2 \cdot 8$ \\
\hline C-49 & $2 \cdot 5$ & $2 \cdot 5$ & 3.5 & $2 \cdot 2$ \\
\hline C-54 & $3 \cdot 0$ & 3.0 & 4.0 & 1.8 \\
\hline C-56 & $2 \cdot 4$ & $2 \cdot 4$ & $3 \cdot 2$ & $2 \cdot 1$ \\
\hline C- 60 & $2 \cdot 9$ & $2 \cdot 9$ & 3.6 & $2 \cdot 3$ \\
\hline C-62 & $2 \cdot 3$ & $1 \cdot 2$ & 3.8 & $+^{*}$ \\
\hline C- 80 & $2 \cdot 7$ & $2 \cdot 1$ & $3 \cdot 3$ & 0 \\
\hline C- 108 & $2 \cdot 6$ & $2 \cdot 9$ & $3 \cdot 2$ & $3 \cdot 2$ \\
\hline C- 155 & $2 \cdot 6$ & $3 \cdot 5$ & $3 \cdot 8$ & $1 \cdot 8$ \\
\hline $\mathrm{C}-180$ & $3 \cdot 2$ & $3 \cdot 2$ & $4 \cdot 4$ & 1.9 \\
\hline C- 187 & 3.9 & $3 \cdot 3$ & 4.0 & $2 \cdot 4$ \\
\hline C- 238 & $2 \cdot 4$ & 1.4 & $3 \cdot 3$ & 0 \\
\hline C. & 2.6 & 3.1 & 3.0 & $3 \cdot 1$ \\
\hline C-249 & 2.2 & 1.9 & 3.0 & 2.0 \\
\hline C-396 & $2 \cdot 8$ & $2 \cdot 5$ & 3.7 & 1.9 \\
\hline C- 605 & 0 & 0 & 2.5 & 0 \\
\hline C-606 & $3 \cdot 8$ & $3 \cdot 3$ & 3.8 & $\pm *$ \\
\hline C- 607 & $4 \cdot 3$ & $3 \cdot 3$ & $3 \cdot 6$ & $\pm^{*}$ \\
\hline Meant & $2 \cdot 89$ & $2 \cdot 67$ & 3.48 & $\overline{2} \cdot 26$ \\
\hline (95\% C.I.) & $(2 \cdot 64-3 \cdot 14)$ & $(2 \cdot 29-3 \cdot 05)$ & $(3 \cdot 23-3 \cdot 73)$ & $(1 \cdot 89-2 \cdot 63)$ \\
\hline
\end{tabular}

* Elastin digestion zone $<1.0 \mathrm{~cm}$.

$\dagger$ The mean value is the average value of the measurable zones only. 


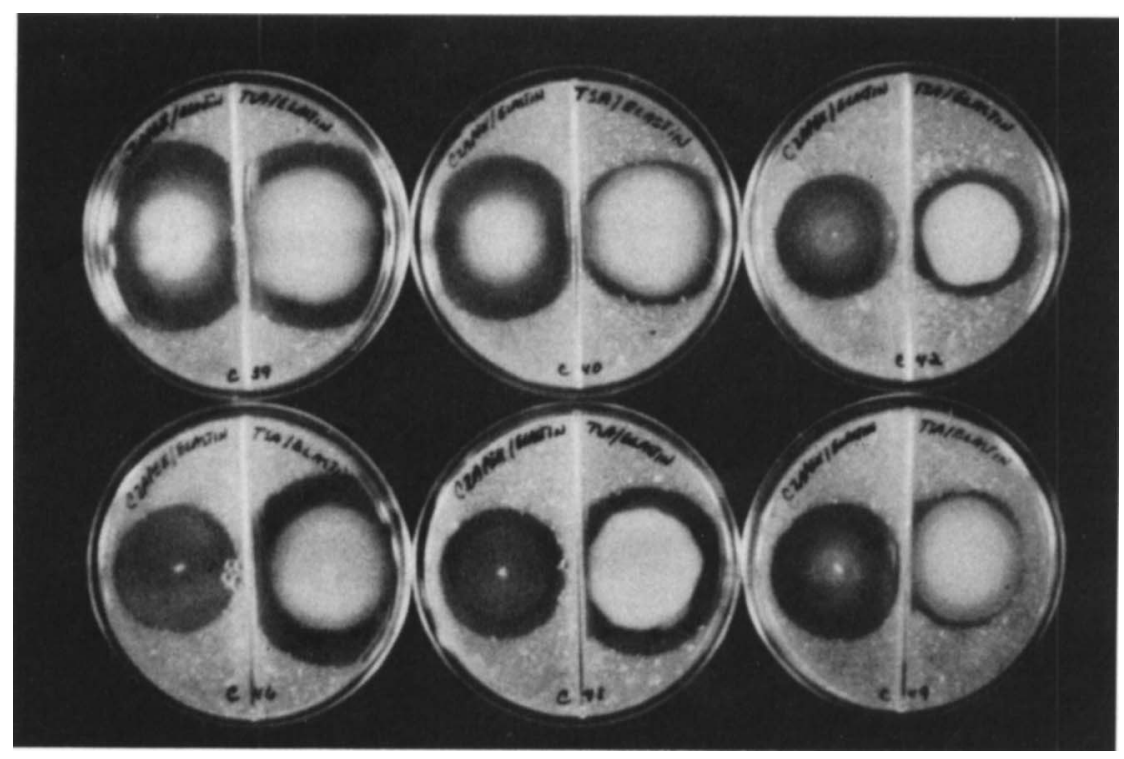

Fig. 2.-Elastase activity of six strains (C39, C40, C42, C46, C48, C49) of C. immitis cultured on Czapek's elastin agar (left half of plate) and Tryptic Soy elastin agar (right half of plate) after incubation at $30^{\circ} \mathrm{C}$ for 1 week and $4^{\circ} \mathrm{C}$ for 2 weeks. Each culture medium was supplemented with bovine elastin $0.5 \%$. Overall increase in elastin hydrolysis at $4^{\circ} \mathrm{C}$ is noticeable when compared to results shown in fig. 1 .

TABLE II

Elastase activity of C. immitis after incubation for 1 week at $30^{\circ} \mathrm{C}$ and 2 weeks at $4^{\circ} \mathrm{C}$ on Czapek's and Tryptic Soy Agar media supplemented with elastin 0.5\%

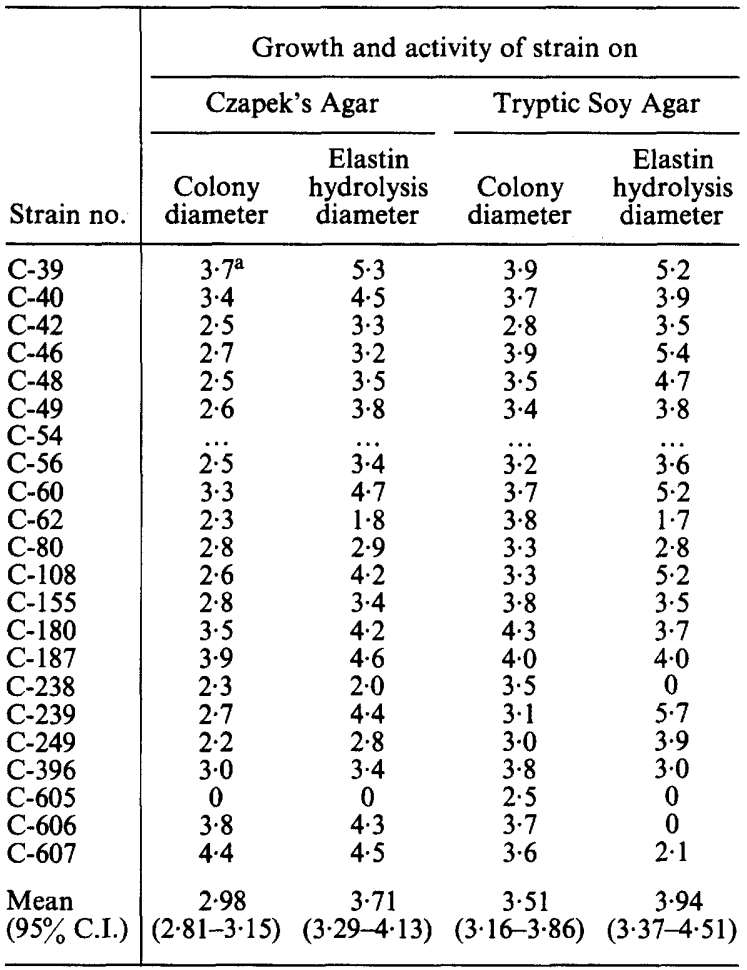

See footnote to table I. 


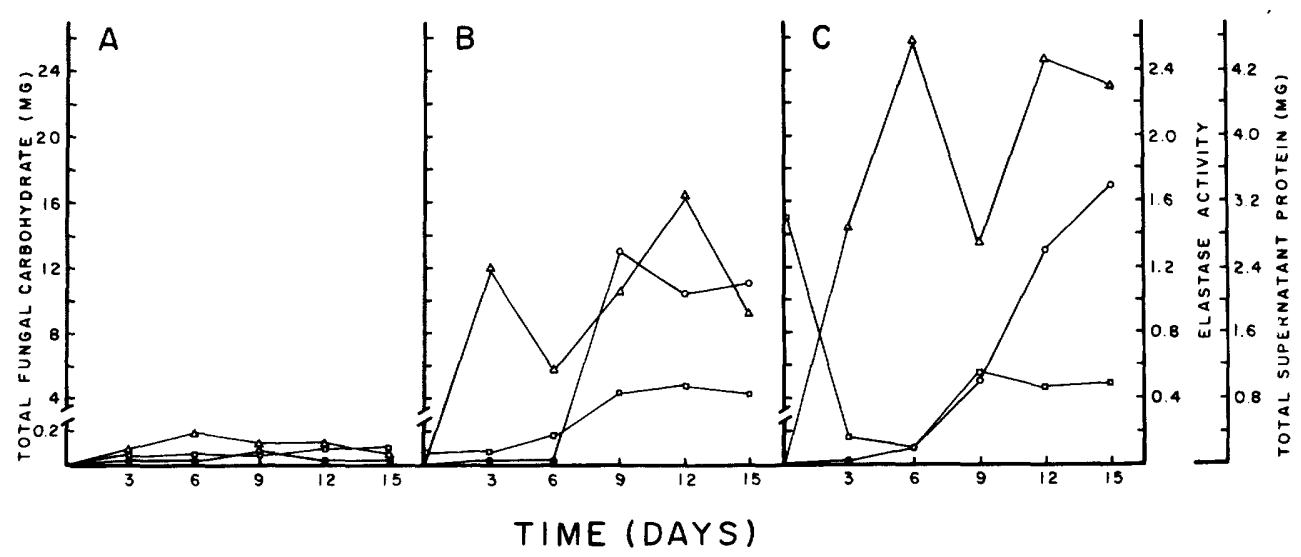

FIG. 3.-Growth of C. immitis strain C-60 in Czapek's fluid (A), Czapek's fluid plus elastin 0.5\% (B), and Czapek's fluid plus elastin $0.5 \%$ and yeast extract $0 \cdot 1 \%$ (C). Each point represents the average of three culture flasks. $-\Delta-=$ Total carbohydrate, $-0-=$ elastase activity and $-\square-=$ total macromolecular protein in supernate of culture broth.

suppressed elastase production. To test this, three sets of fluid cultures containing either CPK only, CPK plus elastin $0.5 \%$ (CPK-E), and CPK plus elastin $0.5 \%$ and yeast extract $0 \cdot 1 \%$ (CPK-E-YE) were seeded with six different strains. The results of the growth of $C$. immitis strain $\mathrm{C}-60$ are shown in fig. 3.

All strains gave visible growth after approximately 3 days; however, the growth in CPK fluid was measured only with difficulty and elastase activity was at baseline levels. In CPK-E fluid (fig. 3, B), strain C-60 started with an early burst of growth that declined by day 6 but returned to maximal levels by day 12 . The later peak of growth was accompanied by an increase in elastase activity and in exocellular protein. The initial peak was probably not a result of elastin digestion because elastase activity was only minimal during this period. A similar pattern occurred with the five remaining strains (data not shown).

The greatest amount of growth occurred in the CPK-E-YE fluid (fig. 3C). The initial peak at 6 days coincided with a decrease in extracellular protein. The extracellular protein consumed was presumably that provided by the yeast extract because elastase activity was not apparent until day 6 . The depression in growth (day 9) and subsequent return to maximal levels (day 12) was concomitantly associated with an increase in elastase activity and extracellular protein. It appeared that strain C-60 utilised the readily available nutrients from the yeast extract before altering its metabolism to hydrolyse the particulate elastin. These results suggest that coccidioidal elastase is inducible and that $C$. immitis would likely utilise other substrates before digesting elastin.

\section{DisCUSSION}

We have confirmed the findings of Rippon and Varadi (1968) who examined the activity of a single strain of $C$. immitis. The results of surveys for fungal elastase (Rippon and Varadi, 1968; Hopsu-Havu et al., 1972) show that $C$. immitis is unique among the dimorphic pathogenic fungi in its ability to digest elastin.

The production of coccidioidal elastase is inducible. When C. immitis was cultured in Czapek's fluid without elastin, very little elastase could be detected by spectrophoto- 
metric assay. However, when elastin was added to the medium, all six strains tested produced elastase. This in-vitro induction does not appear to occur until other nutrients become limiting. This interpretation follows from growth culture analysis in which incorporation of yeast extract into the Czapek's fluid resulted in a delay in elastase production. Similarly, cultivation of $C$. immitis on an enriched semi-solid medium suppressed elastase production and a number of $C$. immitis strains would have been considered negative had they not been also cultured on a minimal (Czapek's) medium.

The delayed elastase activity seen in the enriched (Tryptic Soy) screening agar and in the yeast extract supplemented Czapek's fluid medium suggested that elastase was suppressed by exogenous nutrients.

We have referred to the enzyme digesting elastin as coccidioidal elastase. At present, we do not have sufficient data about the specificity of the elastase of $C$. immitis to determine whether the enzyme is a specific elastase or a general protease which digests elastin.

Elastin is the major structural protein of the lung and comprises a significant portion of other tissues (Frisell, 1982). Elastases have been shown in several animal models of infection to be critical components of bacterial virulence (Holder and Haidaris, 1979; Pavlovskis and Wretlind, 1979; Stewart, 1979; Woods et al., 1982). A similar correlation has been reported for the elastase of the fungus Aspergillus fumigatus by Kothary, Chase, and Macmillan (1984). Such an association has not been made for coccidioidal elastase, nor has it been determined whether coccidioidal elastase is produced by the parasitic form of the fungus. The significance and specificity of coccidioidal elastase will be the subject of future investigations.

\section{REFERENCES}

Dubois M, Gilles K A, Hamilton J K, Rebers P A, Smith F 1956 Colorimetric method for determination of sugars and related substances. Analytical Chemistry 28:350-356.

Frisell W R 1982 Human biochemistry. Macmillan Publishing Co., New York, p 447.

Holder I A, Haidaris C G 1979 Experimental studies of the pathogenesis of infections due to Pseudomonas aeruginosa: Extracellular protease and elastase as in vivo virulence factors. Canadian Journal of Microbiology 25:593-599.

Hopsu-Havu V K, Sonck C E, Tunnela E 1972 Production of elastase by pathogenic and non-pathogenic fungi. Mykosen 15:105-110.

Kothary M H, Chase T, Macmillan J D 1984 Correlation of elastase production by some strains of Aspergillus fumigatus with ability to cause pulmonary invasive aspergillosis in mice. Infection and Immunity 43:320-325.

Lowry O H, Rosebrough N J, Farr A L, Randall R J 1951 Protein measurement with the folin phenol reagent. Journal of Biological Chemistry 193:265-275.

Pavlovskis O R, Wretlind B 1979 Assessment of protease (elastase) as a Pseudomonas aeruginosa virulence factor in experimental mouse burn infection. Infection and Immunity 24:181-187.

Rippon J W, Varadi D P 1968 The elastases of pathogenic fungi and actinomycetes. Journal of Investigative Dermatology 50:54-58.

Sachar L A, Winter K K, Sicher N, Frankel S 1955 Photometric method for estimation of elastase activity. Proceedings of the Society of Experimental Biology and Medicine 90:323-326.

Stewart D J 1979 The role of elastase in the differentiation of Bacteroides nodosus infections in sheep and cattle. Research in Veterinary Science 27:99-105.

Woods D E, Cryz S J, Friedman R L, Iglewski B H 1982 Contribution of toxin A and elastase to virulence of Pseudomonas aeruginosa in chronic lung infections of rats. Infection and Immunity $36: 1223-1228$. 